\title{
The National Youth Service Corps Programme and Growing Security Threat in Nigeria
}

OKAFOR CHUKWUEMEKA | ANI JOHNMARY K.

\section{Abstract}

The National Youth Service Corps the Nigerian civil war to involve Nigerian university graduates below the age of thirty in nation building. Gradually, the scheme was opened-up for polytechnic graduates.

The article presents the objectives and deployment policy of the programme. It shows that the early phase of the programme recorded the problems of corruption, ghost corps members, accommodation, language barriers as well as hostile culture. However, the contemporary Nigerian society has been overtaken by the destructive wind of insecurity. The article reveals that the various waves of political violence in the country, including Boko Haram terrorism, hostage crises, and geographical threats have turned into a collection of overwhelming menace to the programme, thereby leading to massive agitation for its abrogation. The article recommends for multiple series of reforms in order to protect the lives of many Nigerian graduates that are building the nation through this admirable development programme.

Keywords: Youth Service Corps, National Development, Programme, National Integration, Security, Graduates. Nigeria.

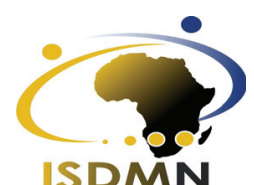

"Africa's Development Watch" 


\section{Background}

The National Youth Service Corps (NYSC) was established in 1973 by the government of General Yakubu Gowon. The historical background of the policy is traceable to the events that took place in Nigeria towards the last half of 1960s. The years 1967-1970 were characterised by the Nigerian civil war. At the end of the war, the General Gowon administration came up with new policies that would promote post-conflict peace, reconciliation, rehabilitation and reconstruction. Consequently, the vital need for national unity led to the birth of the NYSC idea. The NYSC programme was born through Decree $N^{\circ} 24$ of $22^{\text {nd }}$ May 1973. It states that the NYSC is being established with a view to the proper encouragement and development of communities through the youths of Nigeria and the promotion of national unity (NYSC Handbook, 1996). A month later, the ruling military government came up with Decree $N^{\circ} 51$ of $16^{\text {th }}$ June, 1973, which outlined the objectives of the scheme thus:

- To inculcate discipline in Nigerian youths by instilling in them a tradition of industry at work and patriotic as well as loyal service to Nigeria in any situation they may find themselves.

- To raise their morale tone by giving them the opportunity to learn about higher ideals of national achievements, social and cultural improvement.

- To develop in them attitudes of mind, acquired through shared experience and suitable training, which will make them more amenable to mobilization in the national interest.

- To develop common ties among them and promote national unity by ensuring that:

I. As far as possible, youths are assigned to jobs in states other than their states of origin.

II. Each group, assigned to work together, is as representative of the country as possible. 
III. The youths are exposed to the modes of living of the people in different parts of the country with a view to removing prejudices, eliminating ignorance and confirming at first hand the many similarities among Nigerians of all ethnic groups.

- To encourage members of the service corps to seek at the end of their corps service, career employment all over the country thus promoting the free movement of labour.

- To induce employers, partly through their experience with members of the service corps, to employ more readily qualified Nigerians irrespective of their states of origin and,

- To enable Nigerian youths to acquire the spirit of self-reliance.

Onyishi (2011:91) writes that the goal or summary of the objectives of the scheme include to develop a sound and result-oriented institution that is committed to the realization of national unity and even development. It is an organization that is well motivated and capable of bringing out the best qualities in our youth and imparting in them the right attitude and value for nation building that serves as a catalyst to national development and a sense of pride and fulfilment of its participating graduate youths. Obasa (1983:65-69) outlines the set of criterion for corps members' deployment to include:

- the first of these guidelines is the equality of states,

- ability of states to absorb the service of participants,

- posting based on concessional considerations (married women can choose where to be posted),

- posting on demand from various federal government establishments,

- posting of in-service trainees,

- the supportive role of a government is also increasingly becoming a factor in the placement of corps members,

- deployment is affected by the academic and discipline of participants and

- the deployment of corps members has retained its traditional hue-with the majority of corps members going to the classrooms. 
Consequently, a university graduate that has been duly mobilized and documented for the program is generally known as a corp member, while a group of them are commonly referred to as "youth corpers." A graduate is often deployed to any NYSC Orientation Camp (which is often one in each of the thirty-six states of the Federation and the Federal Capital Territory) in any part of the country, in most cases outside his place of birth and domicile. 'It was at first, all inclusive of University graduates, HND and NCE holders but later only degree and HND graduates are required to take part in the compulsory National Youth Service Scheme' (Ohagenyi, 2014).

Those mobilized are trained for three weeks in the different orientation camps. At the end of the training, they would be posted to the areas of primary assignment, where they would stay and work for the remaining part of the service year. The service year is ended with a Passing Out Parade (POP).

However, the contemporary Nigerian society has witnessed the death of some corps members in the states that they were posted to serve. The recent violent killings of many Nigerian graduates serving the country in different towns and cities of the Northern parts of Nigeria, bring to the limelight the negative orgy of violence meted on Nigerians when religious fanaticism and ethnic sentiments is married to desperate desire to rule the nation forcefully, by any segment of the country or religious sect (Okoro \& Ani, 2011:750-760). The laudable scheme which helped most of our present leaders to have a patriotic understanding of fellow Nigerians by appreciating the uniqueness of different nationalities through living and mingling together is now being threatened by insecurity (Ohagenyi, 2014). Consequently, document analysis methodology was adopted in presented clear picture of the security threats faced by corps members. This because "it ought to consign us (all Nigerians) that somehow the NYSC has become a veritable barometer for measuring the degree of security in different parts of the country. When corps members can be posted anywhere in the nation and they complete their service peacefully, then the nation is at peace. The converse is tragically true, which is where we are right now" (Amuta, 2014).

\section{Programme Review}

The NYSC programme has for many years facilitated regular and effective distribution of skilled manpower, steady breaking of social and cultural barriers as well as the building of friendly bridges across ethno-linguistic boundaries. It promoted values of national 
unity and development, rekindled interest in neglected but vital areas of national development like agriculture and promoted leadership qualities in youths. The regular invitation of corps members to participate in the conduct of such sensitive national assignments as census, elections, immunization programme constantly pricks the conscience of the nation to the right course of development (Onyishi 2011:88). The NYSC programme has helped in the educational development of the country, especially from junior secondary to tertiary levels (Aba 2010:145).

Those who share the sentiment of sustaining the scheme like the Arewa Consultative Forum (ACF) state that no other programme in the country best meets objectives of the NYSC. In an editorial, The Tide (2005:4) held that the reasons proffered in 1973 by the Yakubu Gowon administration for the establishment of the NYSC scheme are still very relevant in this country's search for an enduring national unity. There is, therefore, no dispute on the desirability of the scheme and its benefits in our desire to maintain a strong, united and peaceful country despite recent assaults on its integrity. Amongst the corps members themselves, the friendships and endearing marriages the programme has facilitated will remain indelible in the history of the Nigerian nation (Utomwe 2012: 10).

The traditional community development programme which was introduced in the $1976 / 1977$ service year has helped a lot in the promotion of learning, tourism, healthcare and agricultural development. At the end of the 2012 Batch "B" orientation course, 45,000 corps members had been trained in various skill areas. A further breakdown shows that 5,404 were trained in agro-allied skills, 5,509 in food processing and preservation, 8,035 in culture and tourism-related skills and 5,062 in cosmetology. Information and communication technology had 8,119 power and energy 2,885 and environment 2,672. Another set of 2,837 members acquired skills in beautification, 2,057 in construction and 2,425 in education (Utomwen, 2012). All these portray the relevance of the programme in promoting national integration and socio-economic development.

\section{Challenges facing the programme}

There are many challenges that have threatened the existence of the NYSC programme. It should be noted that while the earlier stated objectives of the NYSC programme are noble and targeted at youth empowerment and national development, the reality is that 
the effectiveness of its implementation remains an issue of massive criticism. Again, when the programme started in 1973, corps members are fed in the camp at the rate of three naira per person per day. Ironically, the same amount was used to feed corps members per day for the next ten years, making the then NYSC Director, Col. Peter Obasa to complain that it was grossly inadequate (Obasa, 1983: 70). The issue of Corp members receiving the kind of food that some trained dogs will not accept to eat has remained recurrent in some camps. For instance, the first objective is meant to instil the culture of industry at work; the fact is that some youths hardly engage in the primary assignment they are deployed to do, as they operate as 'ghost' corps members that serves the country in their areas of selfish-interest and visits their main place of NYSC posting during the monthly clearance exercise in order to get the monthly federal government allowance.

Similarly, Onyishi $(2011: 88)$ states that the programme is prone to corruption. There are now permanent youth corps members who never pass out while embezzlement, nepotism, favouritism are now rampant in the scheme. Onyishi (2011) further writes that some federal officials are totally blind, selfish and corrupt; all they care for is what their bank accounts read after each NYSC programme is completed. That is the reason they don't want to scrap NYSC. Report indicate that while the corps members are supposed to serve in their host communities for a year; in reality, less than $30 \%$ of those mobilized actually serve the country, the rest return to their states of origin, only returning to the area of primary assignment during the quarterly and now, monthly screening exercise for payment popularly called alawi. The inspectors have also being accused of getting 50\% or more of the allowances of these 'ghost' corps members for giving them patriotic cover-up (Onyishi, 2011:88-89).

Amuta (2014: 11) has queried the position of those who argue that the NYSC promotes national unity. He states that 'the NYSC programme has united nothing. Nor has it created any more patriotic citizens. Unity and patriotism require more fundamental variables than periodically stuffing young people to places they would rather not go to on a starvation stipend'. The issue of NYSC programme being a platform for learning about higher national ideal is often an ideal dream as the larger Nigerian society is filled with all forms of manipulative and corrupt culture. In short, there are those who believe that the twenty one days orientation camp is often a training ground for those who still had their family and religious virtues to lose it, in the face of the massive dysfunctional 
behaviours experienced in the NYSC camps. The patriotic vision of developing the sense of corporate existence and common destiny of the Nigerian people, which the programme is out to promote has progressively remained a mirage when reviewed in terms of the reality of the recurrent-weekly crisis between one ethnic group and another or one settler-community and another non-settler (aboriginal settlers) of the community.

On July 27, 2010, the Anti-Fraud Unit of Nigerian Security and Civil Defence Corp (NSCDC) arrested 69 suspected fake NYSC members in an illegal orientation camp located in Angwan Lambu, Keffi, and Nasarawa State. There is also the traditional challenge of indiscriminate rejection of corps members in the establishment that they are posted to serve thereby, creating the nightmare of roaming the streets for weeks in search for a new place of primary assignment. It is a very difficult situation that has been worsened by the fact that Nigerian tertiary institutions continue to churn-out graduates without recourse to the ability of NYSC to properly organize orientation for them. This has left the scheme with backlog of graduates awaiting national service for months and sometimes years, a situation that depreciates the quality and motivation of Nigerian youths. A former NYSC Director General, Yusuf Bomoi once lamented that myriads of problems threaten the objectives of the scheme. They include post service unemployment, lack of camp facilities and the challenge of maintaining discipline (Onyishi, 2011:92). The programme has equally suffered from poor financing and sometimes late payment of corps members allowances. Inequality in the amount paid in different places of primary assignment is another factor that makes the corps members to lobby extensively to be posted to high-paying places of primary assignment like banks and oil companies. Ironically,

At the time of its (NYSC) inception, the state of the nation was different... Now, we are in a very different place. Our priority has shifted from national integration and unity towards a crisis of governance and plain simple mismanagement of public expectations. The danger posed by bad governance is today far greater than any threat to national unity. By far the greater threats to Nigeria's future include epic incompetence, the domination of the public services and strategic institutions by expired, incompetent and very corrupt people. Worse still, this arm of the elite has 
organized itself into cabals for the protection of clique interests and huge portions of national wealth. An NYSC scheme that was originally designed to forge cosmetic unity is functionally useless in today's circumstances (Amuta, 2014).

\section{Dimensions of security threats}

The nature of security threats to the programme has grown in scope and dimension. It would be recalled that that the orientation programme for NYSC Batch " $\mathrm{C}$ " members scheduled for $6^{\text {th }}$ November, 2012 for the whole country was postponed in three states Bayelsa, Borno and Yobe - in line with ensuring the safety of corps members. According to a statement issued by the Head of Press and Public Relations Unit in the NYSC Headquarter, Mrs. Abosede Aderibigbe, she stated that the postponement for Bayelsa was prompted by the recent flooding in the state and the subsequent accommodation of displaced victims at the NYSC permanent orientation camp in Kaiama. The postponement for Borno and Yobe was necessitated by security challenges in the states. Consequently, corps members deployed to the three states were directed to undergo their orientation course from $28^{\text {th }}$ November to $19^{\text {th }}$ December. The corps members earlier posted to Yobe were moved to Magaji Dan Yamusa, Keffi, Nasarawa State for their orientation course (Utomwen, 2012). However, the threats to NYSC programme has manifested mainly in the areas of political threats, Boko Haram terror attacks, hostage taking, and geographical threats.

I. Political Threats: The election of President Goodluck Jonathan into office in 2011 triggered the flame of political violence in Northern Nigeria, which led to the killing of a number of corps members. Peter Awelewa, the Bishop, Diocese of Lagos West (Anglican Communion) while reacting to the killing of corps members has stated that 'going by this latest development, it is becoming clear that the North believes that rulers of Nigeria must forever come from among them, while other Nigerians are expected to remain as servants or second class citizens within Nigeria, which rightly belongs to all of us' (Aladelokun, 2011:4). The post-presidential election violence was unfortunate and condemnable. It was a sad signal that rather than improve on their attitude over elections, 
politicians are still desperate, their supporters even more so. While reacting on the killings of these national servants, Wole Soyinka condemned it as a premeditated act. He stated that 'I was really shocked by the note of satisfaction, almost sadistic reaction at the killings... There was always a kind of glory in what was always going on, which made me wonder why we all call ourselves Nigerians. It makes me wonder whether we all have the same project in mind when we go to polls, or whether we all have the same destination in mind, when we embark on events' (Adiorho and Onomo, 2011: 64). About 50 Corps Members were locked inside the Nigerian Christian Corpers' Fellowship (NCCF) Secretariat in the heart of Minna, the Niger State capital, by some youths protesting the results of the presidential election, and the building set on fire. But for the courage of one of the Corps Members, who forced the door open, all the 50 would have died. A female corps member who said she escaped miraculously told tales of how she and other corps members on electoral duty were forced to thumbprint for a particular party in Giade Local Government Area of Bauchi State, tortured and even fondled by the irate protesters, and how eleven of them were butchered like animals (The Nation, 2011:19). Aremu (2014:64) wrote that we have seen the best minds of my generation destroyed by madness of the larger political leaders as they always become victims of war.

II. Boko Haram Terror Attacks: Recently, the Boko Haram sect, backed by their bomb-blast terrorism in Northern Nigeria has practically planted the psychology of fear among parents and Nigerian graduates that are waiting for NYSC deployment. Despite the killing of hundreds of people in Borno state by the outlawed Boko Haram sect, the NYSC deployed 820 corps members to the state after an orientation programme held in Gombe at a time (Ohagenyi, 2014). The media were agog with news of the bombing of the NYSC permanent orientation camp in Maiduguri by the Boko Haram sect. Recently, after the presidential election, the Boko Haram sect struck and killed many Nigerians including corps members. The federal government promised to present five million naira to families of those who lost their lives at the blast. There was also promise of jobs to the other affected corps members immediately after the mandatory one year 
service the nation. Years later, the jobs are still in a shelf and most of the affected graduates roam the streets looking for jobs. The thousands of university graduates that are produced annually often keep their knees on ground as they continually pray for the hands of providence to ensure that they are not posted to the terror-overtaken states of Borno and Yobe. It is part of the Nigerian history that thousands of NYSC members posted to different parts of the North have re-deployed to other states, where the wind of safety is higher in order to ensure that they finish their NYSC programme safely.

III. Hostage crises: The first to disappear was Mr. Bukari I. Bambur, a corps member from North Central State, deployed to Lagos. This was extremely embarrassing to the Directorate as the press gave the case a lot of publicity and the Police Force seemed helpless. We even contacted the Immigration Authorities, in case the young man had decided to leave the country! But our entire search proved abortive. I must say, with regret that until I left Nigeria on $2^{\text {nd }}$ June, 1975 for Addis Ababa-the Bambur case still remained a mystery (Adedeji, 1983: 35).

The above case shows that the disappearance of corps members started in the first few years of the inception of the scheme and as years went on, it turned into a full act of abduction. The recent dastardly act of abduction and raping to death of a female corps member, Grace Adie Ushamg serving in Maiduguri, Borno State capital on $26^{\text {th }}$ September, 2009 for the single offence of wearing khaki trouser forced the media as well as the national assembly to join parents in the debate on the NYSC and security question; what should constitute its nature as well as the implementation process in order to ensure the safety of corps members.

In 2013, three corps members; Ogechi Martins, Chijioke Richard and Esther Nwachukwu were kidnapped from the Ogonokom Corper' Lodge in Rivers State. They were released after ten days in captivity. The Commissioner of Police, Mbu Joseph Mbu added that five suspects were arrested in connection with the abduction of the three corps members (Ogbu, 2013). Similarly, the Corps members that served in Ogun State in 2012 were advised not to put on their NYSC uniform while travelling back home. The advice was given at the passing out parade of more than 3,000 Batch A corps members that served in the state. Aderibigbe (2012) who spoke on behalf of the NYSC 
management reminded NYSC members to be security conscious while returning to their respective homes. Those who passed out from camp were encouraged not to travel in the night. A former Director- General of NYSC decried the spate of kidnapping in the country and submitted that corps members have become part of the target of kidnappers. It would be recalled that recently, five corps members, who donated a library project to a school in Omademe community in Nkwere Local Government Area of Rivers State were abducted while returning from the inspection of the project. The corps members were driving in their colleague's car when the incident occurred. They included four ladies and a male. The male member of those abducted is Olumide Yusuf, a graduate from the Department of Chemical and Polymer, Lagos State University. The Rivers State Police Public Relations Officer, Ben Ugwuegbulam confirmed the abduction, adding that the police was on top of the situation. It would be recalled that a similar incident occurred in Rivers State in 2010. It took the intervention of the army and other security forces to secure the release of the five corps members that were abducted and moved to a community in Abia State.

IV. Geographical threats: Parents of potential corps members as well as serving corps members are constantly afraid of going to the Northern parts Nigeria with history of recurrent violent attacks from Islamist terrorists. The media were overtaken by the overflowing reaction of Nigerian parents when the NYSC authority stated that the scheme will not redeploy corps members posted to volatile parts of Nigeria. Andyanders (2011) was extremely emotional when he wrote:

I wonder why some youths in the name of NYSC certificate want to serve a nation that never saw them through school, only to be killed by northerners. I wonder why you youths call yourselves youths and cannot fight for your right. Why must you not refuse to be sent to Maiduguri or other Northern States? Youths and students, you are all fools, since you cannot tell these old generation that they must not mortgage your lives. If you like, go ahead and answer national death-call by going to 
serve a nation that can never help you, after serving, no job (for the graduate and ex-corper). The need to go to school, is it not to get a paid job, Instead of a paid death (during NYSC)? The people sending you there, their children's-children serve in the South, or they can even buy-off the certificate.

It is no longer folktales but an existential reality that some parents prevent their children going for national service in volatile parts of the country just to ensure that they don't lose them to the disciples of death, found in many parts of Nigeria today. This is because in an increasingly dangerous national space, preferential posting is the sensible thing for parents to opt for. Wanting your ward to serve in a safe place is enlightened self-interest. Those who insist that their wards be posted to safe places are not less patriotic than those who have left the fate of their wards in the hands of the NYSC, only to be greeted with returning coffins a few months into the scheme (Amuta, 2014). It would be recalled that the killing of corps members in some states are still fresh in the minds of Nigerians, coupled with the escalating attacks by Islamists terrorist group, Boko Haram. Some corps members posted to the North had cause to storm the Yakubu Gowon House, headquarters of the NYSC earlier in 2012 to announce their rejection of their posting. They carried placards with inscription, "We prefer to die here instead of being killed by Boko Haram in the North" (Utomwen, 2012). The popular opinion against posting people to violence prone areas, which was a death sentence on thousands of Nigeria graduates forced the House of Representatives to direct the NYSC headquarters to cancel all posting of corps members to volatile states in the North East as it is a general knowledge that the corps members are ill-equipped and ill-trained to defend themselves. The problem of sickness, trauma and diseases that go with environmental change cannot be over-emphasized too.

There is also a security threat emanating from the distance between one part of the country to another. Many corps members have often lost their lives, while others have being seriously injured and handicapped due to the many cases of auto crash that is associated with Nigerian roads. It is no longer a hidden fact of history that corps members have lost their lives in the boat mishaps of the creeks of Niger-Delta, while others have being sent to the great beyond due to the threat of harsh weather in Northern Nigeria. 
The first fatal accident (recorded in the NYSC scheme) occurred on $28^{\text {th }}$ August, 1973 - less than two months after the call-up date. It arose from a motor cycle accident involving a corps member named I. U. Itan, who came from Bessenge near Obudu, in the then South Eastern State, who was serving in Maiduguri. The Nigerian Air Force came to our aid by flying the corpse from Maiduguri to Enugu from where the Director led the funeral procession to the deceased's village where his remains were laid to rest... Regrettably, fatal accidents still continue to happen among corpers (Adedeji, 1983:3435).

\section{Conclusion and Recommendations}

The culture of graduate youths serving their countries has being practiced in different forms in USA, India and Ghana. Since 1973, graduates of Nigerian universities and later polytechnics were required to undergo a year of national service in any part of the country. In 1976, the NYSC programme was extended to HND holders and NCE holders, who were inculcated because of the dire need for teachers that would facilitate the Universal Primary Education (UPE) policy. For very good reasons, the Federal Military Government limited the scheme, initially, to graduates of Nigerian Universities not above the age of 30 who had successfully completed their first degree. In 1977, there was the abolition of the age limit for participation in the scheme, which was later re-introduced and currently pegged at those below thirty years of age, just as the NCE holders has been disbanded from serving the country. It is worthy of note that these group of people that passed out may not be blamed for refusing to accept the theory of settling in the host state because Nigerian history is filled with cases of people that have being retrenched by a state governments, in order to employ their own people, using such professional names like right-sizing and down-sizing.

Notwithstanding the security problems that have befallen the Nigerian state, the country still manages to remain a place of first choice for investment in Africa; hence the NYSC programme can still be factored in promoting sustainable peace and security as well as national development. There is increasing need for progressive re-organization of 
the NYSC in this era multiple security crisis. This is because without the NYSC discharge certificate, the time spent in the university and polytechnic would have been wasted so to say, as nobody would offer a Nigerian graduate a public job without principally requesting for the NYSC certificate. Ironically, it is a popular statement that those NYSC members who have lost their lives to one form of security threat or another are rooted on the fact that they have no option. Unfortunately, as the growing harvest of deaths in national service has become, it should be re-stated that self-preservation is the first law of nature. The corps members who think they have no option than to serve in risky security zones should remember that you need to be alive to take the post-NYSC job and make all the money on earth.

States and services that really require corps members should formally make requisition for them and be ready to enter written undertakings to protect and meaningfully engage these personnel. Increasing insecurity in the land dictates that states take out substantial insurance coverage for corps members they request. This is because, having observed the menace of Boko Haram, kidnapping and growing political violence in the country, there is no doubt that if nothing is urgently done to stem the tide, the NYSC may soon be a thing of the past.

The then leadership of Brigadier General Okorie-Affia once declared the aim of establishing a Distress Call Centre (DCC) for corps members to use during time of distress and security threat. This project is yet to be implemented in the remote areas and is of high importance for the security of corps members. The country's network providers should be approached through a combined effort of the NYSC, National Communication Commission and the Federal Ministries of Information, Communication as well as Defence to see its feasibility. There is need for the extension of the camping period to about three months, during which the corps members would be trained in vocational skills and other entrepreneurial acts that would make them self-reliant and initiators of small and medium scale enterprises after the service year. Finally, there is need for corps members to be posted to their different regions of birth, while other forms of policy reforms should follow-suite. 


\section{List of References}

- Aba, A. A. 2010. Nigerian Politics, 1999-2009: Images from Chinua Achebe's Mirror, in Joseph Mangut and TerhembaWuam (Eds.) The Press and Literature in the Fourth Republic, Markurdi: Aboki Publishers, pp. 133-147

- Adedeji, A. 2014. We Are Not Bothered About Nigeria's Security Problem. Michael Rauterkus, Chief Sales Officer of Europe, Middle East and America for Grohe," The Nation, Friday, March 7, p. 27

- $\quad$ Adedeji, A. 1983. The National Youth Service Corps: Its Genesis and Formative Years; in M. M. Owosina, S. O. Ojo, J. A. Ibitoye, J. Yusuf, M. B. Abodunde, Adamolekun and M. F. Kolajo (Eds.) A Compendium of the National Youth Service Corps Scheme: Ten Years of Service to the Nation, Lagos: Supercolour Productions, pp. 18-47

- Aderibigbe, A. 2012. Kidnapping of NYSC Members. OOU Vanguard Magazine, oouvanguard.blogspot.com/2012/02/kidnapping-of-nysc-members.html $19^{\text {th }}$ February. Retrieved on $1^{\text {st }}$ May, 2014.

- Adiorho, J. and Onomo, A. A. 2011. Soyinka Decries Post-Presidential Polls Violence. The Guardian. Friday. April 29. P. 64.

- $\quad$ Aladelokun, D. 2011. Bishop Seeks Scrapping of NYSC Scheme. The Nation. Friday. April 22. P. 4.

- $\quad$ Amuta, C. 2014. NYSC: Then, Now and Henceforth. http://www.eftngr.com/opal/analysis/46-comment/1363-nysc-then-now-andhenceforth. Retrieved on 1st May, 2014

- Andyanders, 2011. Re: Boko Haram Bombs NYSC Orientation Camp in Maiduguri. www.nairaland.com/712404/boko-haram-bombs-nysc-orientation/2 July 13. Retrieved on $1^{\text {st }}$ May, 2014

- $\quad$ Arabamen, K. 2014. Edo State: NYSC Member, 4 Others Arrested for Alleged Kidnapping. https://www.google.com.ng/?gfe_rd=cr\&ei=zBRIU6eMC8LR8gea3oDoBA\#q=kidnaping+ of + NYSC+members. Retrieved on $4^{\text {th }}$ May, 2014.

- Aremu, F. 2014. The Going Concern of Nigerian State: A Clarion Call to the Youth (2). The Guardian, Thursday, April 3, p. 64

- National Youth Service Corps, 1996, NYSC Handbook, Abuja

- Obasa, P. K. 1983. Consolidation and After, in M. M. Owosina, S. O. Ojo, J. A. Ibitoye, J. Yusuf, M. B. Abodunde, Adamolekun and M. F. Kolajo (Eds.) A Compendium of the National Youth Service Corps Scheme: Ten Years of Service to the Nation, Lagos: Supercolour Productions, pp. 60-122 
- Ogbu, R. 2013. 5 Suspects Arrested over the Kidnapping of NYSC Corps Members in Rivers. www.ynaija.com/5-suspects-arrested-over-the-kidnapping-of-nysc-corps-members-inrivers/ July $9^{\text {th }}$. Retrieved on $1^{\text {st }}$ May, 2014

- Ohagenyi, M. 2014. Boko Haram and Threat to NYSC Programme, https://www.google.com.ng/?gfe_rd=cr\&ei=ighlU-3HIMTR8gePIHABg\#q=pdf+security+threats+to+NYSC Retrieved on $1^{\text {st }}$ May, 2014

- Okoro, S. I. and Ani, K. J. 2011. Transnational Media and the Development of a Progressive Peaceful Political Culture in Nigeria, in Chiegboka, A. B. C., Utoh-Ezeajugh, T. C. \& Ogene, M. S. (Eds.) The Humanities and Sustainable Development, Nimo: Rex Charles \& Patrick Ltd, pp. $750-760$.

- Onyishi, A. O. 2011. Youth and National Development in Nigeria: An Analysis of National Youth Service Scheme: 1999-2009, International Journal of Modern Political Economy, Vol. 2, No. 1, pp. 87-102

- $\quad$ The Nation. 2011. Kudos to Corps Members. Friday. April 22.p. 19.

- The Nation 2010. Akpabio Accuses Opposition of Kidnappings. Friday, February, 5.

- Utomwen, D. 2012. Tackling NYSC's Security Challenge, http://www.pmnewsnigeria.com/2012/12/10/tackling-nyscs-security-challenge/. Retrieved on $1^{\text {st }}$ May, 2014

\section{AUTHORS' CONTACT:}

OKAFOR, Chukwuemeka

Dept of Public Administration University of Fort Hare Email: cokafor@ufh.ca.za
ANI, JohnMary K.

Dept of History and Strategic Studies Federal University, Ndufu-Aliko, Ikwo Ebonyi State, Nigeria

Email: Kani4christ@gmail.com

\section{AFRICA'S PUBLIC SERVICE DELIVERY AND PERFORMANCE REVIEW}

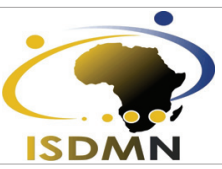

